\title{
Phosphorus and potassium fertilization increase common bean grain yield in Mozambique
}

\author{
Maria da C. S. Carvalho ${ }^{1}$, Adriano S. Nascente ${ }^{1}$, Gilvan B. Ferreira ${ }^{2}$, \\ Celso A. P. Mutadiua ${ }^{3} \&$ José E. Denardin ${ }^{4}$ \\ ${ }^{1}$ Embrapa Arroz e Feijão/Departamento Técnico Científico. Santo Antônio de Goiás, GO. E-mail: maria.carvalho@embrapa.br - ORCID: 0000-0002- \\ 2089-1459; adriano.nascente@embrapa.br (Corresponding author) - ORCID: 0000-0002-6014-3797 \\ ${ }^{2}$ Embrapa Algodão/Departamento Técnico Científico. Campina Grande, PB. E-mail: gilvan.ferreira@embrapa.br - ORCID: 0000-0001-8046-7054 \\ ${ }^{3}$ Ministério das Relações Exteriores/Agência Brasileira de Cooperação. Brasília, DF. E-mail: celsomutadiua@yahoo.com.br - ORCID: 0000-0002-9912-9634 \\ ${ }^{4}$ Embrapa Trigo/Departamento Técnico Científico. Passo Fundo, RS. E-mail: jose.denardin@embrapa.br - ORCID: 0000-0002-8954-7752
}

Key words:

Phaseolus vulgaris yield components soil fertility

\begin{abstract}
A B S T R A C T
There is little information about common bean fertilization in African Savannas. The objectives of this study were as follows: i) to evaluate the common bean yield potential in the environmental conditions of Lichinga, Niassa, Mozambique, and ii) to determine the common bean response to phosphorus and potassium fertilization applied together in order to verify whether the interpretation of soil analysis for the Brazilian Cerrado could be adopted for Savanna soils in Mozambique. The experimental design was a randomized block design in a $5 \times 4 \times 2$ factorial arrangement. Treatments consisted of a combination of phosphorus doses $\left(0,35,70,140\right.$ and $280 \mathrm{~kg} \mathrm{ha}^{-1}$ of $\left.\mathrm{P}_{2} \mathrm{O}_{5}\right)$, potassium doses $(0,50100$ and 200 $\mathrm{kg} \mathrm{ha}^{-1}$ of $\left.\mathrm{K}_{2} \mathrm{O}\right)$, and different growing seasons $\left(2012^{2} / 2013\right.$ and 2013/2014). The field rainfed experiments were conducted in Lichinga city, province of Niassa. Common bean crops presented high productivity potential in rainfed systems in the environmental conditions of Lichinga, Niassa, Mozambique, reaching grain yields of up to 3,600 $\mathrm{kg} \mathrm{ha}^{-1}$ depending on the rates of fertilization with phosphorus and potassium. Common beans responded to phosphorus and potassium fertilization despite high contents of these nutrients in the soil, according to the interpretation of soil analysis for the Brazilian Cerrado. Maximum grain yield in the average of two growing seasons was estimated to occur for $239 \mathrm{~kg} \mathrm{ha}^{-1}$ of $\mathrm{P}_{2} \mathrm{O}_{5}$ and $141 \mathrm{~kg} \mathrm{ha}^{-1}$ of $\mathrm{K}_{2} \mathrm{O}$, indicating that further calibration studies for $\mathrm{P}$ and $\mathrm{K}$ are required for this specific region of Mozambique.
\end{abstract}

\section{Palavras-chave:}

Phaseolus vulgaris componentes de produção fertilidade do solo

\section{Adubação fosfatada e potássica elevam a produtividade de grãos do feijoeiro em Moçambique}

\section{R E S U M O}

Há pouca informação sobre sua fertilização nas Savanas Africanas. Os objetivos deste trabalho foram: i) avaliar o potencial de produtividade de feijão nas condições ambientais de Lichinga, Niassa, Moçambique e ii) determinar as curvas de resposta da cultura à adubação com fósforo e potássio, aplicados juntos, a fim de verificar se a interpretação da análise de solos do Cerrado brasileiro poderia ser adotada para os solos do Cerrado de Moçambique. O delineamento experimental foi em blocos casualizados, em esquema fatorial $5 \times 4 \times 2$. Os tratamentos foram formados pela combinação de doses de fósforo $(0,35,70,140$ e 280 $\mathrm{kg} \mathrm{ha}^{-1}$ de $\left.\mathrm{P}_{2} \mathrm{O}_{5}\right)$ com doses de potássio $\left(0,50100\right.$ e $200 \mathrm{~kg} \mathrm{ha}^{-1}$ de $\left.\mathrm{K}_{2} \mathrm{O}\right)$ e safras agrícolas $(2012 / 13$ e 2013/14). Os experimentos de sequeiro a campo foram realizados na cidade de Lichinga, província de Niassa. A cultura de feijão-comum apresentou alto potencial de produtividade em sistema de sequeiro nas condições ambientais de Lichinga, Niassa, Moçambique, atingindo rendimento de grãos de até $3600 \mathrm{~kg} \mathrm{ha}^{-1}$, dependendo das doses de adubação com fósforo e potássio. O feijão-comum respondeu à fertilização de fósforo e potássio apesar do alto teor desses nutrientes no solo, de acordo com a interpretação da análise do solo para o Cerrado brasileiro. O rendimento máximo de grãos, na média de duas safras, foi estimado em $239 \mathrm{~kg} \mathrm{ha}^{-1}$ de $_{2} \mathrm{O}_{5}$ e $141 \mathrm{~kg} \mathrm{ha}^{-1}$ de $\mathrm{K}_{2} \mathrm{O}$, indicando que estudos de calibração para $\mathrm{P}$ e K são necessários para esta região específica de Moçambique. 


\section{INTRODUCTION}

Over 200 million people in sub-Saharan Africa depend on the common bean (Phaseolus vulgaris L.) as a primary staple (Petry et al., 2015). However, despite the crop's importance, in Africa Savannas, the common bean grain yield achieved by farmers is very low (CGIAR, 2015). During the 2013 growing season in Africa, grain yield was $657 \mathrm{~kg} \mathrm{ha}^{-1}$ and only $345 \mathrm{~kg} \mathrm{ha}^{-1}$ in Mozambique (FAO, 2015). In Brazil, for example, there are farmers reaching yields of $3,500 \mathrm{~kg} \mathrm{ha}^{-1}$ in common beans (Nascente et al., 2012, 2014; CONAB, 2017).

The Triangular Co-operation Programme for Agricultural Development of the Tropical Savannah in Mozambique (Pro SAVANA, 2014) is a large project created to investigate new agricultural development models. The target area was the Nacala corridor, an area of 11 million ha that ranges from the border of Mozambique with Malawi to the port of Nacala on the west coast of the country. This area has the same latitude as the Cerrado Region in Brazil, with similar conditions of climate and soil. The main objective was to bring technologies used in Brazil to be tested in the Nacala corridor (Pro SAVANA, 2014). For example, currently there are no regional calibration studies that can be used to recommend $\mathrm{P}$ and $\mathrm{K}$ fertilization for crops, such as the common bean, based on soil analysis.

The common bean is a high demand plant for nutrients, and thus low natural soil fertility is one of the major factors that can limit productivity of this crop in tropical regions (Ávila et al., 2012; Fageria \& Nascente, 2014; Argaw et al., 2015; Silva et al., 2016). Therefore, to avoid soil impoverishment and reduced productivity over time, it is necessary to replace at minimum the quantity of nutrients exported by the grains. In addition, there has been increasing demand for fertilizer recommendations covering the major foods and cash crops in Mozambique (Geurts \& Berg, 1998). The objectives of this study were as follows: i) to evaluate the common bean yield potential in the environmental conditions of Lichinga, Niassa, Mozambique, and ii) to determine the common bean response to phosphorus and potassium fertilization in order to verify whether the interpretation of soil analysis for the Brazilian Cerrado could be adopted for the Savanna soils of Mozambique.

\section{Material AND Methods}

The study was conducted in the experimental field of the Centro Zonal de Investigação Noroeste (CZINw), of the Instituto de Investigação Agrícola de Moçambique (IIAM), in the district of Lichinga, province of Niassa, located in northern Mozambique, with coordinates of $13^{\circ} 23^{\prime} 48^{\prime \prime} \mathrm{S}$ and $35^{\circ} 13^{\prime}$ $43^{\prime \prime} \mathrm{E}$. The altitude of the region varies from 1000 to $1300 \mathrm{~m}$. According to the classification of Köppen-Geiger (1928), the climate of this region is humid temperate (Cwb), with two well-distinguished seasons (temperate and rainy summers and dry cold winters). The region presents average annual rainfall varying between 1000 and $1500 \mathrm{~mm}$, while the average annual temperature is between 20 and $23{ }^{\circ} \mathrm{C}$ (Mbanze et al., 2015). The temperature and rainfall data during the trials are shown in Figure 1.
The soil was classified as a clay loam Ferralsols (FAO, 1998). The experiments were repeated in adjacent areas in the same field. Before the trials were set up, in September 2012, soil chemical analyses were performed at a depth of 0-0.20 m to characterize the experimental area (Table 1). The chemical analyses were performed according to the methodology proposed by Donagema et al. (2011).

The experimental design was a randomized block design in a $5 \times 4 \times 2$ factorial arrangement, with four replications. For each growing season, the trial was located in different locations within the same larger area, which was sampled for soil analysis in both growing seasons (Table 1). Treatments were the combination of phosphorus doses $\left(0,35,70,140\right.$ and $280 \mathrm{~kg} \mathrm{ha}^{-1}$ of $\left.\mathrm{P}_{2} \mathrm{O}_{5}\right)$, potassium doses $\left(0,50,100\right.$ and $200 \mathrm{~kg} \mathrm{ha}^{-1}$ of $\left.\mathrm{K}_{2} \mathrm{O}\right)$, and growing season (2012/13 and 2013/14). The sources of these nutrients were triple superphosphate and potassium chloride.

The soil was prepared with conventional tillage (one plowing and two disking). The sowing of the rainfed common bean cultivar BRS 'Pontal' was manually completed on December $12^{\text {th }}, 2012$ and January $15^{\text {th }}, 2014$, with a row spacing of $0.45 \mathrm{~m}$ and a density of 8 seeds $\mathrm{m}^{-1}$. Each plot consisted of five rows six meters long, with a useful area of three central rows, disregarding $1.5 \mathrm{~m}$ from the ends of each row. A sowing fertilization was applied with $23 \mathrm{~kg} \mathrm{ha}^{-1}$ of $\mathrm{N}$ as urea, and a topdressing fertilization at the $\mathrm{V}_{4}$ vegetative stage of the common bean (three trifoliate leaves) was applied with 67 $\mathrm{kg} \mathrm{ha}^{-1}$ of $\mathrm{N}$ as urea. Other cultural practices were performed according to the recommendations for the crop to keep the area free of weeds, diseases and insects. Harvesting occurred on March 21 ${ }^{\text {st }}, 2013$ and May 9 ${ }^{\text {th }}, 2014$.

The usable area of the plots was harvested by hand, followed by a mechanized thresher. The harvested common bean grains were weighed, and the yield was adjusted to $130 \mathrm{~g} \mathrm{~kg}^{-1}$ of water content. In addition, the following yield components were assessed: the number of pods per plant, the number of grains per pod (evaluated in 10 plants per plot that were chosen at random), and the 100-grain weight (calculated from eight random samples per plot) corrected to $130 \mathrm{~g} \mathrm{~kg}^{-1}$ of water content.

Data were subjected to analysis of variance, and means were compared using Tukey's test at $\mathrm{p}<0.05$. Regression analysis was conducted for quantitative data ( $\mathrm{P}$ and $\mathrm{K}$ rates) if they were found to be significant. SAS statistical software was used for these analyses.

\section{Results AND Discussion}

The number of pods per plant, the number of grains per pod and the 100-grain weight are the main components of common bean grain yield (Fageria \& Santos, 2008). Analysis of variance revealed no effects of $\mathrm{P}$ or $\mathrm{K}$ fertilization on the number of grains per pod or on the 100-grain weight (Table 2 ). The number of grains per pod is a characteristic specific to each cultivar and is genetically determined with little influence from the environment (Pelá et al., 2009). Although strongly genetically controlled, the 100-grain weight is also influenced by environmental conditions, such as soil $\mathrm{pH}$ and $\mathrm{N}, \mathrm{P}$ and 
A. 30

60

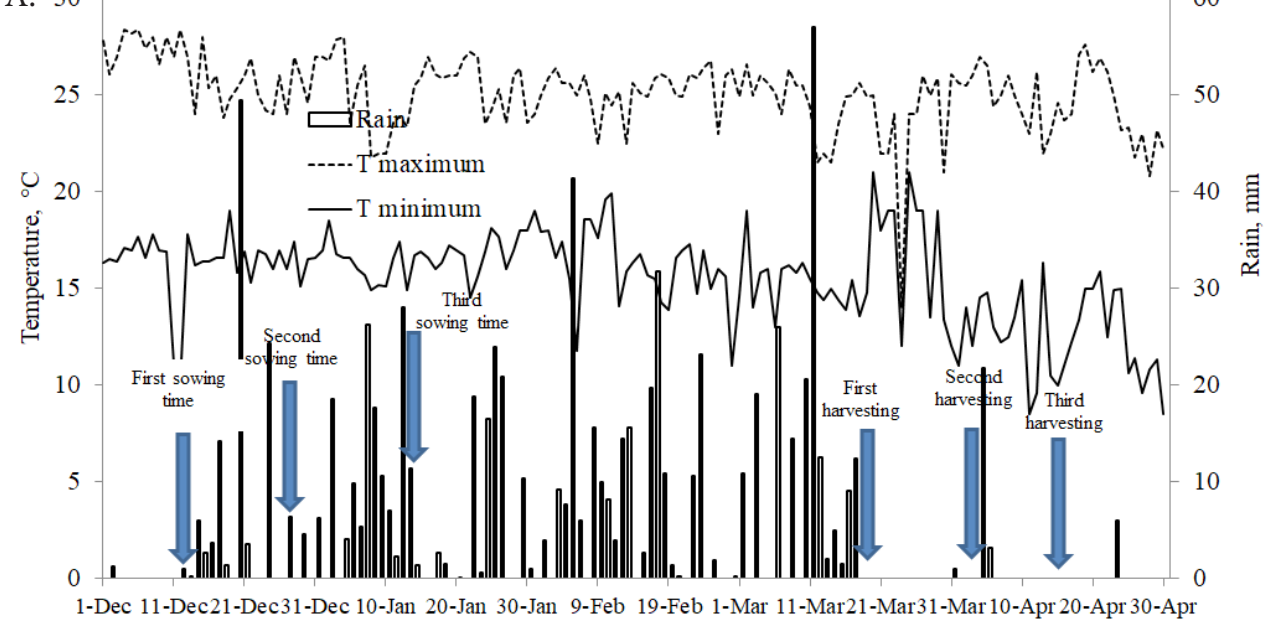

Period of the trial

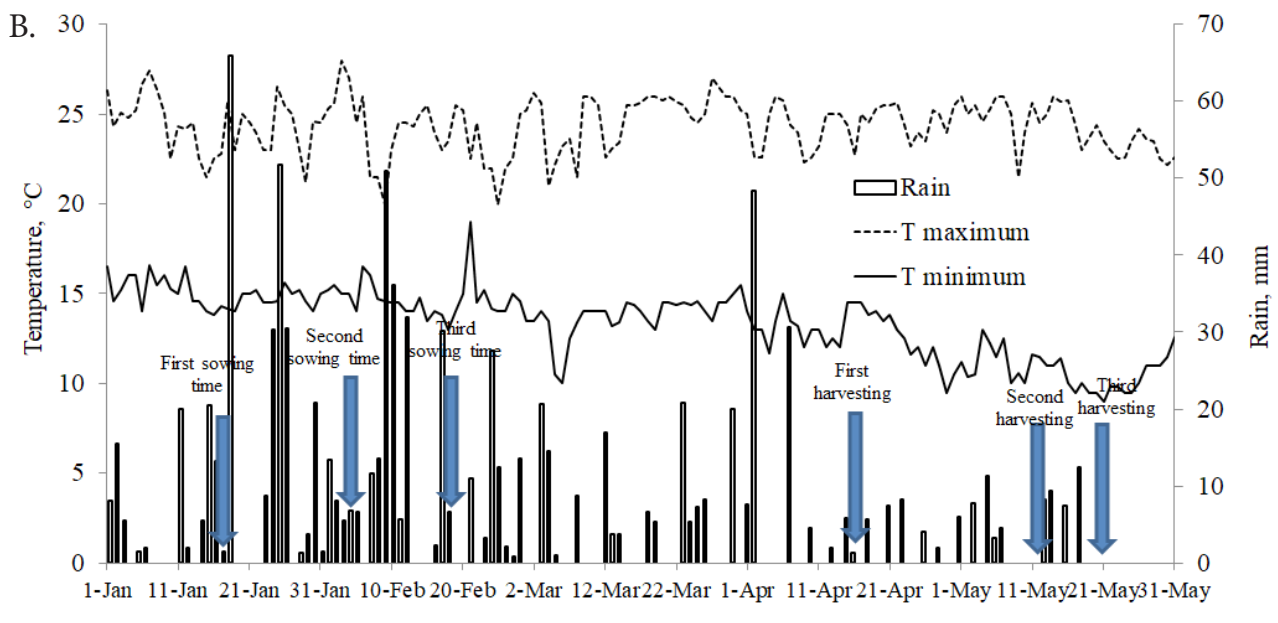

Period of the trial

Figure 1. Temperature and rainfall of the experimental area during the trials performed in the growing seasons 2012/13 (A) and 2013/14 (B)

Table 1. Soil property results of the experimental area. Lichinga city, province of Niassa, Mozambique. Growing seasons 2012/13 and 2013/14

\begin{tabular}{|c|c|c|c|c|c|c|c|c|}
\hline \multicolumn{9}{|c|}{ Growing season 2012/13 } \\
\hline \multirow{2}{*}{ Layer } & ${ }^{1} \mathrm{P}$ & ${ }^{1} \mathrm{~K}^{+}$ & $\mathrm{Al}^{+3}$ & $\mathrm{Ca}^{+2}$ & $\mathrm{Mg}^{+2}$ & \multirow{2}{*}{$(\mathrm{Ca}+\mathrm{Mg}) / \mathrm{K}$} & \multirow{2}{*}{$\mathrm{Ca} / \mathrm{K}$} & \multirow{2}{*}{$\mathrm{Mg} / \mathrm{K}$} \\
\hline & $\mathrm{mg} \mathrm{kg}^{-1}$ & \multicolumn{4}{|c|}{$\mathrm{mmol}_{\mathrm{c}} \mathrm{kg}^{-1}$} & & & \\
\hline $0-0.20 \mathrm{~m}$ & 23 & 3.0 & 6.5 & 11.5 & 4.5 & 5.3 & 3.8 & 1.5 \\
\hline \multirow[t]{3}{*}{$\mathrm{IBC}^{2}$} & High & High & High & Low & Low & Low & Low & Low \\
\hline & \multirow{2}{*}{$\begin{array}{c}\mathrm{pH} \\
\text { in water }\end{array}$} & $\mathrm{H}+\mathrm{Al}$ & CEC & & & \multirow{2}{*}{$\begin{array}{l}\text { BS } \\
\%\end{array}$} & SOM & Clay \\
\hline & & \multicolumn{3}{|c|}{$\mathrm{mmol}_{\mathrm{c}} \mathrm{kg}^{-1}$} & & & \multicolumn{2}{|c|}{$\mathrm{g} \mathrm{kg}^{-1}$} \\
\hline $0-0.20 \mathrm{~m}$ & 6.1 & 54.9 & \multicolumn{2}{|c|}{73.8} & & 19.0 & 24 & 440 \\
\hline $\mathrm{IBC}^{2}$ & Good & High & Medium & & & Low & Medium & Clay \\
\hline \multicolumn{9}{|c|}{ Growing season 2013/14 } \\
\hline & $\mathbf{P}$ & $\mathrm{K}^{+}$ & $\mathrm{Al}^{+3}$ & $\mathrm{Ca}^{+2}$ & $\mathrm{Mg}^{+2}$ & \multirow{2}{*}{$(\mathrm{Ca}+\mathrm{Mg}) / \mathrm{K}$} & \multirow{2}{*}{$\mathrm{Ca} / \mathrm{K}$} & \multirow{2}{*}{$\mathrm{Mg} / \mathrm{K}$} \\
\hline & $\mathrm{mg} \mathrm{kg}^{-1}$ & \multicolumn{4}{|c|}{$\mathrm{mmol}_{\mathrm{c}} \mathrm{kg}^{-1}$} & & & \\
\hline $0-0.20 \mathrm{~m}$ & 23 & 3.0 & 6.7 & 11.0 & 4.4 & 5.1 & 3.7 & 1.5 \\
\hline \multirow[t]{3}{*}{$\mathrm{IBC}^{2}$} & High & High & High & Low & Low & Low & Low & Low \\
\hline & \multirow{2}{*}{$\begin{array}{c}\mathrm{pH} \\
\text { in water }\end{array}$} & $\mathrm{H}+\mathrm{Al}$ & CEC & & & \multirow{2}{*}{$\begin{array}{c}\text { BS } \\
\%\end{array}$} & SOM & Clay \\
\hline & & & $\mathrm{mmol}_{\mathrm{c}} \mathbf{k g}^{-}$ & & & & \multicolumn{2}{|c|}{$\mathrm{g} \mathrm{kg}^{-1}$} \\
\hline $0-0.20 \mathrm{~m}$ & 6.3 & 55.1 & 72.7 & & & 18.0 & 23 & 440 \\
\hline $\mathrm{IBC}^{2}$ & Good & High & Medium & & & Low & Medium & Clay \\
\hline
\end{tabular}

CEC - Cation exchange capacity; ECEC - Effective cation exchange capacity; BS - Base saturation; SOM - Soil organic matter; Al saturation (Al/ECECx100) $=29 \% ;{ }^{1} \mathrm{P}$ and $\mathrm{K}$ were extracted by Mehlich-1; ${ }^{2}$ Interpretation for Brazilian Cerrado soils, Sousa \& Lobato (2002)

K fertilization (Fageria et al., 2001; Fageria \& Santos, 2008). However, 100-grain weight was not affected by $\mathrm{P}$ or K doses in our trial, likely because the content of these nutrients in the soil (Table 1) was not limiting to grain filling. Corroborating these results, Zucareli et al. (2006), Pelá et al. (2009), Zucareli et al.
(2011) and Nascente \& Cobucci (2015) found no significant differences in the number of grains per pod or 100-grain weight with increasing levels of $\mathrm{P}$ in the soil. Rodrigues et al. (2013) also did not report differences in the number of grains per plant with the increasing K levels. Thus, it can be inferred 
Table 2. Number of pods per plant (PODS), number of grains per pod (GRAIN), 100-grain weight (100G) and grain yield (YIELD) of the common bean cultivar 'BRS Pontal' as a function of phosphorus and potassium fertilization and analysis of variance in the growing seasons 2012/2013 and $2013 / 2014$

\begin{tabular}{lcccc}
\hline \multicolumn{1}{c}{ Factors } & PODS & GRAIN & 100G & YIELD \\
Growing season & number & number & $\mathrm{g}$ & $\mathrm{kg} \mathrm{ha}^{-1}$ \\
$2012 / 2013$ & $17.9 \mathrm{a}^{*}$ & 6.7 & 27.3 & $2796 \mathrm{a}$ \\
$2013 / 2014$ & $16.7 \mathrm{~b}$ & 6.3 & 27.2 & $2499 \mathrm{~b}$ \\
\hline \multicolumn{4}{c}{ ANOVA F value (F probability) } \\
Rates of $\mathrm{P}_{2} \mathrm{O}_{5}(\mathrm{P})$ & $<0.001$ & 0.3514 & 0.2874 & $<0.001$ \\
Rates of $\mathrm{K}_{2} \mathrm{O}(\mathrm{K})$ & $<0.001$ & 0.3001 & 0.3481 & $<0.001$ \\
Growing season (GS) & 0.0398 & 0.0716 & 0.4018 & $<0.001$ \\
$\mathrm{P} \times \mathrm{K}$ & 0.3217 & 0.3216 & 0.4179 & $<0.001$ \\
$\mathrm{P} \times \mathrm{GS}$ & 0.4461 & 0.2418 & 0.3519 & 0.0235 \\
K x GS & 0.5016 & 0.4664 & 0.6915 & 0.0247 \\
$\mathrm{P} \times$ K x GS & 0.7998 & 0.6789 & 0.7731 & 0.0331 \\
C.V. $(\%)$ & 21.94 & 8.25 & 9.62 & 15.46 \\
\hline
\end{tabular}

that to achieve high grain yield, these nutrients should be in an adequate balance.

There were significant single effects of $\mathrm{P}$ and $\mathrm{K}$ rates and growing season for the number of pods per plant (Table 2). Increasing $\mathrm{P}$ and $\mathrm{K}$ levels resulted in an increased number of pods per plant and were fitted to quadratics equations, which resulted in a maximum of 17.49 pods per plant for doses of $295 \mathrm{~kg} \mathrm{ha}^{-1}$ of $\mathrm{P}_{2} \mathrm{O}_{5}$ and $254 \mathrm{~kg} \mathrm{ha}^{-1}$ of $\mathrm{K}_{2} \mathrm{O}$ (Figure 2). According to Fageria \& Santos (2008), among the yield components, the number of pods per plant is the most important factor that determines grain yield of the common bean because of its higher and more consistent correlation with grain yield. The number of pods per plant is genetically controlled and is also strongly influenced by environmental factors and management
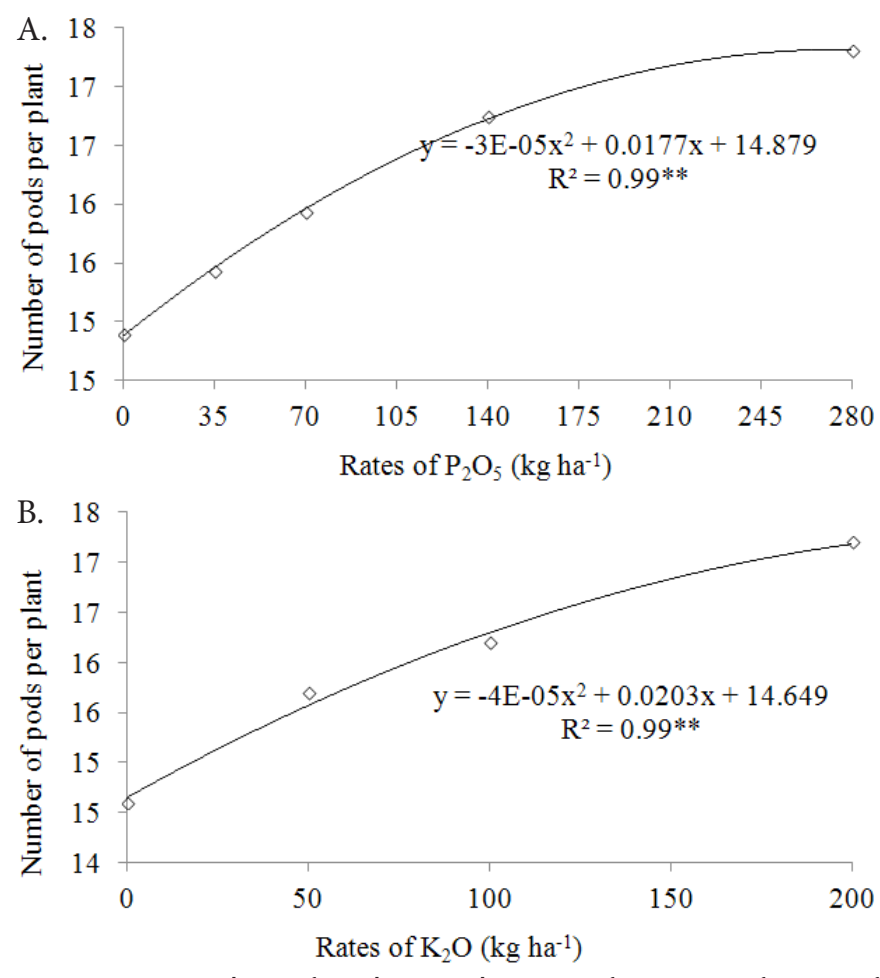

Figure 2. Number of pods per plant as a function of rates of $\mathrm{P}_{2} \mathrm{O}_{5}(\mathrm{~A})$ or $\mathrm{K}_{2} \mathrm{O}(\mathrm{B})$. Average of growing seasons 2012/2013 and $2013 / 2014$ practices, such as $\mathrm{P}$ and $\mathrm{K}$ fertilization, as shown in this study. Phosphorus acts as an energy transfer agent within the plant, playing an essential role in physiological and biochemical processes such as photosynthesis and respiration (Hawkesford et al., 2012). Potassium also has various important physiological functions contributing to plant growth and grain yield, such as photosynthesis, enzyme activity, protein synthesis, cell elongation, translocation and utilization of photosynthates, and osmoregulation (Hawkesford et al., 2012). Thus, any factor impairing P or K uptake by common bean plants can negatively affect plant development, pod filling, and consequently, grain yield. Zucareli et al. (2006, 2011), Pelá et al. (2009), Santos et al. (2011), Silva et al. (2014) and Nascente \& Cobucci (2015) also reported increases in the number of pods per plant due to increased levels of $\mathrm{P}$ fertilization.

There was a significant triple interaction between $\mathrm{P}$ and $\mathrm{K}$ fertilization, growing seasons, and grain yield (Table 2 ). In both growing seasons, the variation of common bean grain yield in response to $\mathrm{P}$ and $\mathrm{K}$ rates was adjusted by a response surface model, and the inflection point (or maximum point) ranged from one growing season to another (Figure 3). In the growing
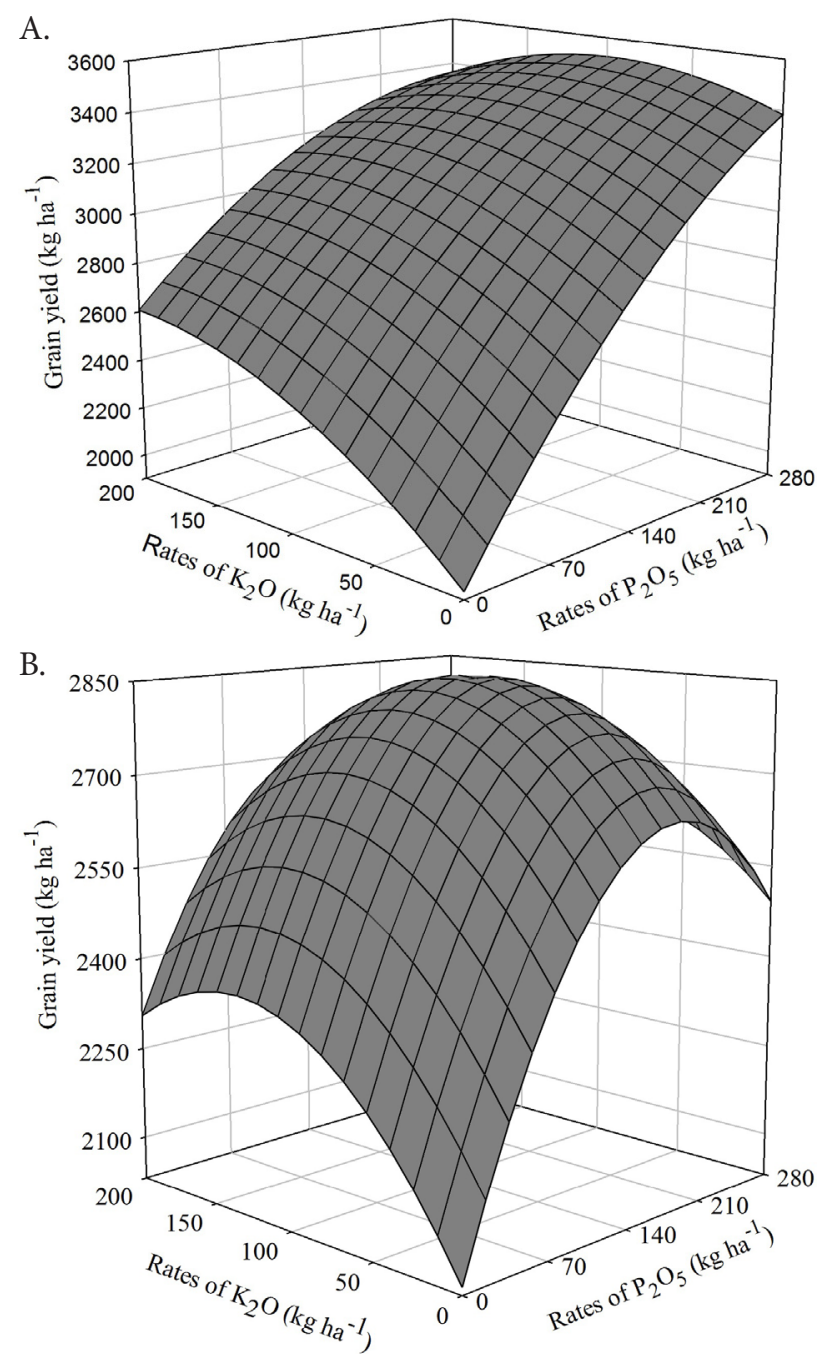

Response surface $(A)$ : Yield $=1930+7.63 \mathrm{P}+6.35 \mathrm{~K}-0.0087 \mathrm{P}^{2}-0.0125 \mathrm{PK}-0.0148 \mathrm{~K}^{2}$ $R^{2}=0.63(p<0.01)$.

Response surface $(B)$ : Yield $=2042+6.56 \mathrm{P}+4.975 \mathrm{~K}-0.0177 \mathrm{P}^{2}-0.0063 \mathrm{PK}-0.0183 \mathrm{~K}^{2}$ $R^{2}=0.63(p<0.01)$

Figure 3. Grain yield of common bean cultivar BRS Pontal as a function of $P$ and $K$ fertilization in the growing season 2012/13 (A) and 2013/14 (B) 
season $2012 / 13$, the maximum grain yield of $3616 \mathrm{~kg} \mathrm{ha}^{-1}$ was estimated with the combined rates of $406 \mathrm{~kg} \mathrm{ha}^{-1}$ of $\mathrm{P}_{2} \mathrm{O}_{5}$ and $43 \mathrm{~kg} \mathrm{ha}^{-1}$ of $\mathrm{K}_{2} \mathrm{O}$ (Figure $3 \mathrm{~A}$ ). In growing season 2013/14, the maximum grain yield of $2616 \mathrm{~kg} \mathrm{ha}^{-1}$ was estimated with the combined rates of $166 \mathrm{~kg} \mathrm{ha}^{-1}$ of $\mathrm{P}_{2} \mathrm{O}_{5}$ and $107 \mathrm{~kg} \mathrm{ha}^{-1}$ of $\mathrm{K}_{2} \mathrm{O}$ (Figure 3B). In the Brazilian Cerrado region, common bean yield is not expected to respond positively to the application of $\mathrm{P}$ and $\mathrm{K}$ in soils with high content of these nutrients (Table 1). The positive effects in the Nacala corridor region, even at $\mathrm{P}$ and $\mathrm{K}$ levels considered to be high in soils from the Brazilian Cerrado (Fageria et al., 2001; Sousa \& Lobato, 2002), indicate that calibration studies for $\mathrm{P}$ and $\mathrm{K}$ are required for this specific region of Mozambique. It was observed that $\mathrm{Ca}$ and $\mathrm{Mg}$ contents in the soil were low and that exchangeable Al was high, resulting in low base saturation in the soil (Table 1). This implies unfavorable conditions for the development of the root system (Silva et al., 2004) and, therefore, lower uptake of nutrients by plants due to the exploitation of the small soil volume. Föhse et al. (1988) demonstrated that the common bean is a low $\mathrm{P}$ uptake efficiency species, with both a low rootshoot ratio and a low influx rate. Therefore, the magnitude of the common bean response to $\mathrm{P}$ fertilization depends in part on root development, which is influenced by base saturation of the soil (Silva et al., 2004).

The decrease in grain yield after a maximum point in both growing seasons (Figure 3) was likely the result of adverse interactions between excess $\mathrm{P}$ and $\mathrm{K}$ and other nutrients in the rhizosphere. It is known that excess phosphorus, for example, causes decreases in zinc uptake (Singh et al., 1988; Fageria et al., 2010). An excess of $\mathrm{K}$ further decreases the ratios ( $\mathrm{Ca}+$ $\mathrm{Mg}$ ) $/ \mathrm{K}, \mathrm{Ca} / \mathrm{K}$ and $\mathrm{Mg} / \mathrm{K}$, which were already very low (Table 1). In the Brazilian Cerrado, which has similar conditions to those in Mozambique soil, it is assumed that the ratios between these cations are $(\mathrm{Ca}+\mathrm{Mg}) / \mathrm{K}=20$ to $30, \mathrm{Ca} / \mathrm{K}=15$ to 25 , and $\mathrm{Mg} / \mathrm{K}=5$ to 15 (Sousa \& Lobato, 2002). Therefore, in this study, in addition to the absolute levels of $\mathrm{Ca}$ and $\mathrm{Mg}$ in the soil being low (Table 1), the ratios of these two nutrients to $\mathrm{K}$ are also very low. This likely resulted in the impaired uptake of $\mathrm{Ca}$, and especially of $\mathrm{Mg}$, in the roots as higher doses of potassium were applied to the soil.

Based on the average results of the 2012/2013 and $2013 / 2104$ harvests (Table 2), it can be inferred that the common bean confirmed its high nutritional requirements, especially for phosphorus, by responding to balanced fertilization with increasing grain yield. In the regression analysis of the two growing seasons, grain yield corresponded to $\mathrm{P}$ and $\mathrm{K}$ rates according to quadratic equations (Grain yield $=2264+6.62 \mathrm{P}-0.013 \mathrm{P}^{2}, \mathrm{R}^{2}=0.93^{\star *}$; Grain yield $=2460$ $\left.+4.60 \mathrm{~K}-0.016 \mathrm{~K}^{2}, \mathrm{R}^{2}=0.63^{\star}\right)$, and the maximum grain yield was estimated using the rates of $239 \mathrm{~kg} \mathrm{ha}^{-1}$ of $\mathrm{P}_{2} \mathrm{O}_{5}$ and $141 \mathrm{~kg} \mathrm{ha}^{-1}$ of $\mathrm{K}_{2} \mathrm{O}$. However, the results of production for only two harvests, without proper monitoring of soil fertility and nutritional status of the crops and without knowledge of market indicators and input prices are insufficient to establish $\mathrm{P}$ and $\mathrm{K}$ rates for optimum economic yield.

The results indicate that there were differences in the number of pods per plant and in grain yield of the common bean for both growing seasons (Table 2). The number of pods per plant and the grain yield were higher in the 2012/2013 harvest compared to $2013 / 2014$. This is possibly because in $2012 / 13$, there was a rainfall of $322.6 \mathrm{~mm}$ during the flowering and grain filling stages, and in the 2013/14 growing season, there was a rainfall of $234 \mathrm{~mm}$ during this same period (Figure 1). This lack of rainfall in the second growing season in relation the first likely affected the number of pods per plant, which was greater in the first growing season. According to Guimarães et al. (2011), during the flowering and grain filling stages, common bean plants require increased amounts of water, and a deficit drastically reduces yield components and grain yield. In addition, Zucareli et al. (2006) reported that the number of pods is the variable that most strongly influences common bean yield. However, it is noteworthy that the grain yields were highly satisfactory, with values higher than the average typical for Mozambique of $345 \mathrm{~kg} \mathrm{ha}^{-1}$ (FAO, 2015). The average grain yield of $2796 \mathrm{~kg} \mathrm{ha}^{-1}$ in 2012/2013 and $2499 \mathrm{~kg} \mathrm{ha}^{-1}$ in 2013/2014 (Table 2) is much higher than the Mozambique average and is also higher than the average productivity of rainfed systems in Brazil, which was $1795 \mathrm{~kg} \mathrm{ha}^{-1}$ in the first season and $893 \mathrm{~kg} \mathrm{ha}^{-1}$ in second season (CONAB, 2017). Based on these results, it can be inferred that Lichinga has good environmental conditions for common bean development and good management practices, such as adequate fertilization with $\mathrm{P}$ and $\mathrm{K}$ can effectively increase the grain productivity of common bean crops in Lichinga, Niassa, Mozambique, Africa. These data are very important and indicate further opportunities to expand food production in places that have serious problems of malnutrition and hunger (CGIAR, 2015).

\section{Conclusions}

1. Common bean crops presented high productivity potential in rainfed systems in the environmental conditions of Lichinga, Niassa, Mozambique, reaching grain yields of up to $3600 \mathrm{~kg} \mathrm{ha}^{-1}$ depending on the rates of fertilization with phosphorus and potassium.

2. Common bean crops responded to phosphorus and potassium fertilization despite high contents of these nutrients in the soil, according to the interpretation of soil analysis for the Brazilian Cerrado. Maximum grain yield, in the average of two growing seasons, was estimated to occur with $239 \mathrm{~kg} \mathrm{ha}^{-1}$ of $\mathrm{P}_{2} \mathrm{O}_{5}$ and $141 \mathrm{~kg} \mathrm{ha}^{-1}$ of $\mathrm{K}_{2} \mathrm{O}$, indicating that further calibration studies of $\mathrm{P}$ and $\mathrm{K}$ are required for this specific region of Mozambique.

\section{ACKNOWLeDgments}

The authors would like to acknowledge Embrapa, the Brazilian Cooperation Agency and the Institute of Agricultural Research of Mozambique for financial support for this project. The authors would also like to thank the CNPq for the productivity grant in research awarded to the second author.

\section{Literature Cited}

Argaw, A.; Mekonnen, E.; Muleta, D. Agronomic efficiency of $\mathrm{N}$ of common bean (Phaseolus vulgaris L.) in some representative soils of Eastern Ethiopia. Cogent Food \& Agriculture, v.1, p.1-15, 2015. https://doi.org/10.1080/23311932.2015.1074790 
Ávila, F. W.; Faquin, V.; Silva, D. R. G.; Bastos, C. E. A.; Oliveira, N. P.; Soares, D. A. Phosphite as phosphorus source to grain yield of common bean plants grown in soils under low or adequate phosphate availability. Ciência e Agrotecnologia, v.36, p.639-648, 2012. https://doi.org/10.1590/S1413-70542012000600006

CGIAR - Consultative Group on International Agricultural Research. Common bean. 2015. Available on: <http://www.cgiar.org/ourstrategy/crop-factsheets/beans/>. Acessed on: Oct. 2016.

CONAB - Companhia Nacional de Abastecimento. Acompanhamento da safra brasileira grãos. 2017. Available on: <http://www.conab. gov.br/OlalaCMS/uploads/arquivos/17_02_16_11_51_51_ boletim_graos_fevereiro_2017.pdf >. Acessed on: May 2017.

Donagema, G. K.; Campos, D. V. B.; Calderano, S. B.; Teixeira, W. G. Manual de métodos de análise de solo. 2.ed. Rio de Janeiro: Embrapa Solos, 2011. 230p.

Fageria, N. K.; Barbosa Filho, M. P.; Costa, J. G. C. da. Potassium-use efficiency in common bean genotypes. Journal of Plant Nutrition, v.24, p.1937-1945, 2001. https://doi.org/10.1081/PLN-100107605

Fageria, N. K.; Nascente, A. S. Management of soil acidity of South American soils for sustainable crop production. Advances in Agronomy, v.128, p.221-275, 2014. https://doi.org/10.1016/B9780-12-802139-2.00006-8

Fageria, N. K.; Santos, A. B. dos. Yield physiology of dry bean. Journal of Plant Nutrition v. 31, p.983-1004, 2008. https://doi. org/10.1080/01904160802096815

Fageria, N. K.; Santos, A. B. dos; Moreira, A. Yield, nutrient uptake and changes in soil chemical properties as influenced by liming and iron application in common bean in a no-tillage system. Communications in Soil Science and Plant Analysis, v.41, p.17401749, 2010. https://doi.org/10.1080/00103624.2010.489137

FAO - Food and Agriculture Organization. World Reference base for soil resource FAO. 84 World Soil Resource Reports. Rome: FAO, 1998.

FAO - Food and Agriculture Organization. FAOSTAT - Food and Agriculture Data - Production: Crops. 2015. Available on: $<$ http:// faostat.fao.org >. Acessed on: Oct. 2016.

Föhse, D.; Claassen, N.; Jungk, A. Phosphorus efficiency of plants: I. External and internal $\mathrm{P}$ requirement and $\mathrm{P}$ uptake efficiency of different plant species. Plant and Soil, v.110, p.101-109, 1988. https://doi.org/10.1007/BF02143545

Geurts, P. M. H.; Berg, M. van den. A simple agro-ecological zonation for fertilizer recommendations in Mozambique. Soil Use and Management, v.14, p.136-141, 1998. https://doi. org/10.1111/j.1475-2743.1998.tb00138.x

Guimarães, C. M.; Stone, L. F.; Peloso, M. J. del; Oliveira, J. P. de. Genótipos de feijoeiro comum sob deficiência hídrico. Revista Brasileira de Engenharia Agrícola e Ambiental, v.15, p.649-656, 2011. https://doi.org/10.1590/S1415-43662011000700001

Hawkesford, M.; Horst, W.; Kichey, T.; Lambers, H.; Schjoerring, J.; Moller, I. S.; White, P. Functions of macronutrients. In: marschner, P. (ed.). Mineral nutrition of higher plants. 3.ed. New York: Elsevier, 2012. Chap.6, p.171-178. https://doi.org/10.1016/ B978-0-12-384905-2.00006-6

Köppen, W.; Geiger, R. Klimate der Erde. Gotha: Verlag Justus Perthes. 1928. Wall-map $150 \mathrm{~cm} \times 200 \mathrm{~cm}$.

Mbanze, A. A.; Batista, A. C.; Tetto, A. F.; Koehler, H. S.; Manteiga, J. B. Influence of the meteorological conditions on forest fires occurrences in Lichinga district, northern Mozambique. Revista Floresta, v.45, p.577-586, 2015. https://doi.org/10.5380/ rf.v45i3.33742
Nascente, A. S.; Cobucci, T. Soil phosphorus availability and dry bean yield as affected by the application of liquid calcium carbonate micron particles on the furrow. African Journal of Agricultural Research, v.10, p.1840-1851, 2015. https://doi.org/10.5897/ AJAR2014.8694

Nascente, A. S.; Cobucci, T.; Sousa, D. M. G. de; Lima, D. de P. Adubação fosfatada no sulco e foliar afetando a produtividade de grãos do feijoeiro comum. Semina: Ciências Agrárias, v.35, p.12311240, 2014. https://doi.org/10.5433/1679-0359.2014v35n3p1231

Nascente, A. S.; Kluthcouski, J.; Crusciol, C. A. C.; Cobucci, T.; Oliveira, P. de. Adubação de cultivares de feijoeiro comum em várzeas tropicais. Pesquisa Agropecuária Tropical, v.42, p.407-415, 2012. https://doi.org/10.1590/S1983-40632012000400003

Pelá, A.; Rodrigues, M. S.; Santana, J. da S.; Teixeira, I. R. Fontes de fósforo para a adubação foliar na cultura do feijoeiro. Scientia Agraria, v.10, p.313-318, 2009. https://doi.org/10.5380/rsa. v10i4.14855

Petry, N.; Boy, E.; Wirth, J. P.; Hurrell, R. F. Review: The potential of the common bean (Phaseolus vulgaris) as a vehicle for iron biofortification. Nutrients, v.7, p.1144-1173, 2015. https://doi. org/10.3390/nu7021144

Pro SAVANA- Triangular Co-operation Programme for Agricultural Development of the Tropical Savannah in Mozambique. 2014. Available on: <http://www.prosavana.gov.mz/>. Acessed on: May 2017.

Rodrigues, M. A. de C.; Buzetti, S.; Maestrelo, P. R.; Lino, A. C. M.; Teixeira Filho, M. C. M.; Andreotti, M.; Garcia, C. M. de P. Cloreto de potássio revestido em efeito residual no feijoeiro de inverno irrigado na região de cerrado. Semina: Ciências Agrárias, v.34, p.1011-1022, 2013. https://doi.org/10.5433/1679$0359.2013 \mathrm{v} 34 \mathrm{n} 3 \mathrm{p} 1011$

Santos, J. Z. L.; Furtini Neto, A. E.; Resende, A. V. de; Carneiro, L. F.; Curi, N.; Moretii, B. da S. Resposta do feijoeiro à adubação fosfatada em solos de cerrado com diferentes históricos de uso. Revista Brasileira de Ciência do Solo, v.35, p.193-202, 2011. https://doi.org/10.1590/S0100-06832011000100018

Singh, J. P.; Karamanos, R. E.; Stewart, J. W. B. The mechanism of phosphorus-induced zinc deficiency in bean (Phaseolus vulgaris L.). Canadian Journal of Soil Science, v.68, p.345-358, 1988. https://doi.org/10.4141/cjss88-032

Silva, D. A. da; Esteves, J. A. de F.; Gonçalves, J. G. R.; Azevedo, C. V. G.; Ribeiro, T.; Chiorato, A. F.; Carbonell, S. A. M. Evaluation of common bean genotypes for phosphorus use efficiency in Eutrophic Oxisol. Bragantia, v.75, p.152-163, 2016. https://doi. org/10.1590/1678-4499.454

Silva, D. A. da; Esteves, J. A. de F.; Messias, U.; Teixeira, A.; Gonçalves, J. G. R.; Chiorato, A. F.; Carbonell, S. A. M. Efficiency in the use of phosphorus by common bean genotypes. Scientia Agricola, v.71, p.232-239, 2014. https://doi.org/10.1590/S010390162014000300008

Silva, L. M. da; Lemos, L. B.; Crusciol, C. A. C.; Feltran, J. C. Sistema radicular de cultivares de feijão em resposta à calagem. Pesquisa Agropecuária Brasileira, v.39, p.701-707, 2004. https://doi. org/10.1590/S0100-204X2004000700012

Sousa, D. M. G.; Lobato, E. Cerrado: Correção do solo e adubação. Planaltina-DF: Embrapa Cerrados, 2002. 416p. 
Zucareli, C.; Prando, A. M.; Ramos Junior, E. U.; Nakagawa, J. Fósforo na produtividade e qualidade de sementes de feijão Carioca Precoce cultivado no período das águas. Revista Ciência Agronômica, v.42, p.32-38, 2011. https://doi.org/10.1590/S180666902011000100005
Zucareli, C.; Ramos Júnior, E. U.; Barreiro, A. P.; Nakagawa, J.; Cavariani, C. Adubação fosfatada, componentes de produção, produtividade e qualidade fisiológica em sementes de feijão. Revista Brasileira de Sementes, v.28, p.9-15, 2006. https://doi. org/10.1590/S0101-31222006000100002 